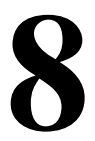

\title{
NIGERIA-AFRICA RELATIONS UNDER ECONOMIC DIPLOMACY, 1988-1992: AN ASSESSMENT OF THE AFRICAN CENTRE-PIECE POLICY
}

\author{
Hassan A. Saliu
}

\section{INTRODUCTION}

Scholars and commentators on Nigeria's foreign policy even before the attainment of independence had conferred on the country the leadership role in Africa ${ }^{1}$. Usually, such scholars have argued that based on the size of the country, its enormous natural resources and high population, Nigeria is a destined leader of Africa. Consequently, after the attainment of independence, in 1960, the country began to formulate a foreign policy that would enable it to play her historic leadership role in Africa. Thus, the African centre-piece principle was consciously accepted as a paramount principle of Nigeria's foreign policy. ${ }^{2}$

Over the years, various regimes in the country have striven to uphold this principle in the country's relations with the rest of the world. In this paper, therefore, an attempt is made to examine Nigeria-Africa relations in the latter part of the Ibrahim Babangida regime (1988-1992). The objectives of the paper are: to find out whether Nigeria, under the regime had placed African issues on its top priority agenda and to find out the extent to which the requirements of economic diplomacy enabled the country to play its anticipated economic developer role in Africa. However, to be able to do this, we have decided to follow this introduction up with a conceptualization of economic diplomacy and framework of analysis after which we attempt a survey of Nigeria - Africa relations before 1988 to provide a pillar on which our analysis on 
Nigeria-Africa Relations Under Economic Diplomacy, 1988-1992

The relationship between 1988-1992 would rest. Of course, the concluding remarks constitute the end of the presentation.

\section{CONCEPTUALIZATION OF ECONOMIC DIPLOMACY VS'D FRAMEWORK OF ANALYSIS}

The thrust of economic diplomacy was a policy response of the Babangida administration to the perennial stress in the national economy. In the view of the government, an economic breakthrough in Nigeria could only be possible through the strengthening of the relationship between the West and the country. This, the regine first dramatized in 1986 through the adoption of a structural adjustment programme (SAP). The failure of SAP to energize western participation in the economy to the level anticipated by the policy makers created the need to search for another policy formula that could beef up the indispensable Western support. This, the regime found in the concept of economic diplomacy which it adopted in June 1988. According to Ibrahim Babangida:

The new thrust of our foreign policy is economic diplomacy. The basic objectives are the fostering of great inflow of foreign capital and the expansion of foreign trade. The foreign policy of any country unquestionably remains one of the major instruments not just for advancing political interests in inter-state relations, but also as a means of enhancing national economic growth and development. ${ }^{3}$

The Babangida administration had also provided additional reasons why economic diplomacy was adopted. Apart from the requirements of SAP regime, it was its conviction that the then imminent collapse of Apartheid and attainment of independence by Namibia signalled the end of decolonization principle upon which the country had made an impressive outing and, therefore, called for another linchpin in the country's external relations. ${ }^{4}$ Furthermore, the then impending European Union was interpreted as a possibility which added weight to the cause of integration in Africa, using the subregional bodies such as ECOWAS as spring boards. The benefits accruable to the country from a possible shift in policy to the South were also glowingly displayed as providing a rationale for the adoption of economic diplomacy in $1988 .{ }^{5}$

Although, all these reasons were argued with varying degrees of persuasion and commitment, it may still be difficult for many objective analysts to agree with the apostles of economic diplomacy that all the signals had decidedly pointed in the 
direction of the thrust. Nevertheless, some mechanisms were put in place to further the cause of pursuing economic diplomacy. These ranged from administrative, diplomatic, trade fairs to investment promotional activities both at home and abroad and incentive regimes. For instance, the ministry of foreign affairs was restricted in order to strengthen its hold on the conduct of Nigeria's external relations. The Trade and Investment Unit created within the ministry was aimed at creating awareness among Nigerian entrepreneurs and their foreign counterparts about the favourable investment climate abroad and at home. A strong collaboration was also attempted between the ministry and all other agents concerned with the formulation and implementation of Nigeria's foreign policy. On the diplomatic front, visa requirements were abolished for the Commonwealth and African citizens coming to Nigeria in order to encourage a high rate of interaction which is necessary for economic transactions. ${ }^{6}$ The President and his Foreign Affairs Minister embarked on extensive diplomatic tours aimed at selling the favourable investment climate in the country to the outside world. The country's ambassadors were not left out of the conduct of economic diplomacy. They were to conduct themselves in a manner that would bring economic support for Nigeria. Indeed, their achievements would be measured strictly in economic terms. ${ }^{7}$

The thrust of economic diplomacy was assigned some other objectives in addition to those given by Ibrahim Babangida above. A government source identified the following as the core objectives of economic diplomacy:

i. $\quad$ the elevation of national economic interest in foreign policy priorities;

ii. the articulation and adoption of strategies that will promote the implementation of domestic economic objectives;

iii. increase coordination with the relevant home ministries as well as active collaboration with the organized private sector (OPS) in the realization of the goals of economic diplomacy;

iv. the reorganization of the foreign service to facilitate the achievement of national economic objectives; and

v. the promotion by the Ministry of Foreign Affairs of joint economic commissions between Nigeria and other countries. ${ }^{8}$

These objectives should not be considered exhaustive. Many other objectives were added at some other times which gave the impression that the thrust of economic diplomacy meant to the Babangida regime a panacea to all problems. ${ }^{9}$ However, Joy Ogwu and Adebayo Olukoshi who pierced through the official mind argued robustly that: 
The chief aim (of economic diplomacy) is to achieve the country's further integration into the international capitalist division of labour. Indeed, in some of the of his pronouncements on the matter, Nwachukwu has been emphatic that the aim (of) economic diplomacy is to further open up Nigeria to foreign/international economic forces since, in his thinking, the country needs those forces for its development. ${ }^{10}$

The heavy external mix in Nigeria's economic diplomacy cannot be in doubtA statement credited to Ike Nwachukwu, who Miss Judith Attah once described as the sole initiator of the thrust reveals this.

As you will recall, we embarked on SAP, the structural adjustment programme, which meantTesourcing our economy and there was no way we could do this without international community supporting our administration... so, we fashioned out a new policy which we termed economic diplomacy."

Two important points need to be noted here. One, although by the realities of Nigeria's political economy, the country has been historically attracting resources mainly from the West, the desperation with which the state sought for Western support even at the expense of national prestige under the Babangida military presidency would suggest a remarkable reduction in the capacity of Nigeria to confront the West even on African affairs in which the former had an interest. Secondly, the African sector in our thinking came third in terms of importance. Obviously, the West came first while the Asian tigers and other newly industrializing countries (NICs) came second. However, another strong contradiction is noted here. How can Nigeria which is increasingly dependent on the West lay claim to being the defender of African rights in a world in which the latter calls the shots?

Repeatedly, the dependency school has been arguing that with the structures of the economy handed over to Third World nations by the colonial masters after the attainment of flag independence, there is no way these countries can be economically independent. Although their submissions have been appreciated, their conclusion has somewhat exposed itself to attacks. It is really half-truth to believe that only external factors can adequately explain the realities of the political economy in the Third World. ${ }^{12}$ Some considerations internal to these countries have also been observed to work for the sustenance of the conditions of dependency. Nonetheless, the thesis of the dependency school applies to the conduct of Nigeria's economic diplomacy under the Babaginda administration. 
It is incontestable that Nigeria, since independence, has been dependent on the West. However, the adoption of SAP and later, economic diplomacy, anticipated the strengthening of the dependent relationship between the former and the latter. The further deepening of the economic crisis in the 1980s created a conviction in the minds of the decision makers that the path of salvation lay in close attachment to the Western countries. This dependency, however, carried with it some repercussions for Nigeria's African policy. Thus our hypothesis is that an African country that depends heavily on the extra-continental powers for the resolution of her economic crisis is more likely to water down her commitment to African affairs. Apparently aware of the probable conflict between the old political commitments in Africa and the larger requirements of economic diplomacy, the Babangida regime had assured foreign policy elites that it would be fair to both in the implementation of economic diplomacy. ${ }^{13}$ But between 1988 and 1992 when the air was thick in the conduct of the thrust, the view of the foreign policy students was that some African affairs were compromised for the wider interests of economic diplomacy. This arose principally from the dependency of Nigeria on the West through the instrumentality of economic diplomacy. And this understanding leads us to the question of appropriateness of the concept of economic diplomacy to Third World nations. Ayo Amale remarks:

The economic instruments of foreign policy have a bias for developed states which are in a good position to subordinate other states. They are of limited relevance to most Third World states that are not in a position to offer economic benefits or prove to be a positive threat to other states ....' ${ }^{4}$

In addition, a country that looks at economic diplomacy in terms of deliverance from economic crisis must of necessity empty her foreign policy of any traces of radical impulse. Rabid pursuit of a continental agenda must have to give way to the dictates of extra-continental powers whose actions or inactions impact on the foreign policy objectives of the state.

\section{A SURVEY OF NIGERIA-AFRICA RELATIONS BEFORE 1988}

In carrying out its task under this heading, the paper will utilize the objectives of Nigeria's foreign policy as its framework of analysis. By this, we mean that the analysis in this section will be tailored along the lines of the consistent objectives which the country's foreign policy is set to achieve. These objectives include: 
protection of the territorial integrity of the nation, promotion of economic development in Nigeria and Africa, eradication of all traces of colonialism and racism from the African continent, promotion and protection of the rights of black men all over the world and promotion of international peace.

The first objective which is widely referred to in the literature as the core objective is the protection of the territorial integrity of the nation. ${ }^{15}$ It is a statement of fact that it is when a nation is secure in her territorial boundaries that she can aspire to achieve other categories of objectives which have been ranked as secondary and Utopian respectively. With respect to Africa, the theatre for achieving this objective has been extended to the West Africa sub-region. It was reasoned that since there was relative social balance in the country, the sector from which a credible threat could come to Nigeria's territorial integrity was West Africa. Although weaker than Nigeria, the West African countries could be used as proxies, by notably, France and South Africa to attack the country. ${ }^{16}$ Consequently, the pursuit of this objective has necessarily gone beyond the conventional purview of a territorial entity.

To illustrate this, hi the early 1960s when there was bitter rivalry between Nigeria and Ghana over which one of them should lead Africa, a couple of calculated attempts, as recorded in Ibrahim Gambari's book, were made to subvert each other's sovereignty. ${ }^{17}$ Opposition elements from Ghana were warmly received in Nigeria. Not only that, the Nigerian media were placed at their disposal. The Ghanaian authorities too, paid Nigeria back in her own coins. To demonstrate her level of dislike for Nigeria, the Ghanaian authorities rejoiced when Sir Tafawa Balewa was assassinated in January, 1966. In a similar vein, Nigeria began to be more involved in the intractable political crisis in Chad when it began to be of serious security concern to her.

Twice Nigeria had dispatched troops to Chad. In the second case, in 1981, her role in the dislodgement of the Goukoni Waddaye's group was widely acknowledged. Not because Waddaye was indispensable but because his dethronement, instead of promoting Nigeria's interest there, seemed to have promoted the interests of the West who had lured the Shagari government into the venture even at the risk of constitutional provisions. However, the Shagari government rationalized its involvement on the ground of protecting the territorial integrity of Nigeria. An escalation of the crisis could spill over to Nigeria in view of their common borders. ${ }^{18}$

Although debatable, the closure of borders with Nigeria's neighbours between 1984-1985 had been rationalized on the grounds of security needs at the time. ${ }^{19}$ Similarly, the policy of expulsion of illegal aliens in 1981 and 1985 were linked with the security imperatives of the Nigerian state. ${ }^{20}$

The second objective could be said to be an instrument towards making the Nigerian state secure from internal and external threats. More precisely, Nigeria's 
foreign policy has as one of its objectives, the promotion of economic development of Nigeria and improvement of the living standards of Africans. The country had really done much to achieve this objective of her foreign policy. Being located in a sub-region which has a preponderance of economically poorer nations (mostly Francophone), she felt that her lack of concern for their economic well-being would necessarily make them fall prey to Nigeria's adversary outside the region. In the wider African context, the same thinking prevailed but it was re-inforced by the "giant" syndrome.

Creating good living standards for Nigerians would make them unwilling accomplices in an external design to destabilize the nation. In the same manner, catering for the economic needs of Africans, would reduce the chances of any of the countries being used against Nigeria's interests.

The Balewa government strove hard to demonstrate this concern for African economic development but the poor economic base and the delicate political balance at home, marked its era out as low key. ${ }^{21}$ However, some joint ventures were established under it. One major incident that seemed to have revolutionalized Nigeria's foreign policy was the civil war that took place between 1967 and 1970. The war really drove home the point that there is a correlation between the economic health - of Nigeria and that of her poor African neighbours. ${ }^{22}$

Mainly as a result of the civil war and the good state of the economy, aid of different kinds were extended to African countries. For example, the decision of the Yakubu Gowon administration to sell oil at concessionary prices to African countries who had refineries was resorted to in order not to afford Saudi Arabia any opportunity to be a regular participant in African affairs, the acute dependence of the Nigerian state on oil revenue notwithstanding. Equatorial Guinea, Liberia, Benin, Togo, etc. benefited substantially from the economic largesse of the country. Many joint ventures were established to further develop the economies of African states. To date, Nigeria has investment in Benin, Guinea, Liberia, Zambia, among other countries. ${ }^{23}$

With the worsening economic crisis in Africa, Nigerian took the lead in advertising its ramifications to the rest of the world. She, therefore, hosted the first OAU Economic Summit in April, 1980. She was also instrumental to the convening of the second OAU Economic Summit in 1985. At the latter summit, a programme of action was adopted against African Economic crisis. In the following year, in concert with other African countries, Nigeria caused an extra session of the UN General Assembly to be convened on the African economic crisis. At the Assembly, a four year programme of action for African Economic Recovery and Development was adopted. In view of the more crippling effect of indebtedness in Africa, Nigeria played a lead role in the adoption of an OAU common position on African debt 
crisis in 1987 which revolved around the cancellation of all bilateral debts and the massive injection of funds into Africa to support the structural adjustment programme ("SAP). Manpower, as another element of development, has been impeding development in Africa. Towards resolving this, Nigeria initiated the Technical Aid Corps (TAG) in 1987 whereby the surplus manpower in the country could be sent to needy African countries. ${ }^{24}$

The third objective, like the proceeding one, bears some semblance to the first objective. The existence of colonialism and racism in Africa was viewed by the policy makers as a credible threat to Nigeria's negotiated independence. Therefore, eradication of all forms of colonialism and racism in Africa was set as an important objective of Nigeria's foreign policy in 1960. To this end, the country was a more vocal voice against colonialism and Apartheid in South Africa. She followed up her verbal condemnation of these evils with concrete support for the liberation movements. Nigeria's efforts in this regard under the First Republic was, however, moralistic. The civil war clearly exposed the limitations of the earlier approach. With the support given to the Biafran Republic by South Africa, the Nigerian state was woken up from its slumber. ${ }^{25}$ The continuous existence of the Apartheid state was a serious security risk to the country. Consequently, moral, financial and diplomatic support were stepped up for the liberation movements. Guinea Bissau, Angola, Moxambique, among other countries, were ably assisted in their liberation wars. To hasten Rhodesia's independence, the Obasajo regime nationalized the assets of BP in Shell-BP and to cushion the effect of the incessant attacks of South Africa on the Frontline States, the country donated N50m to Zambia and Namibia in $1986 .{ }^{26}$ It is appropriate to remark that the inept, corrupt and inefficient leadership which the Second Republic government offered the country dented the anti-colonial and anti-Apartheid record of Nigeria. The government was not only indebted to the OAU Liberation Committee but also defaulted in her contribution to the regular OAU budget. ${ }^{27}$ The country was, however, saved from further embarrassment by the Buhari administration. The Ibrahim Babangida regime carried the country's anti-Apartheid posture a little further. It strengthened the country's participation in the UN anti-Apartheid committee and continued for a while to press for the continued imposition of sanctions on the Apartheid state. Cumulatively, therefore, Nigeria shares in the glory of the collapse of Apartheid in 1994.

It could be discerned from Nigeria's foreign policy that the promotion and the protection of the rights of black men all over the world is one of its objectives. This objective, however, belongs to the Utopian class. ${ }^{28}$ All the same, Nigeria did try to publicize the indignities that black men were subjected to in the world. The state also identified with the aspirations of the blacks in diaspora. Under the Yakubu 


\section{Annals of The Social Science Council of Nigeria, No. 7, January-December, 1995}

Gowon government, the Nigerian state paid the salaries of civil servants in Grenada, its obvious long distance notwithstanding. ${ }^{29}$ Towards uniting all blacks, the country hosted the World Festival of Arts and Culture in 1977. Many bilateral agreements were signed between Nigeria and Jamaica within the period under review.

Another objective of Nigeria's foreign policy is the promotion of international peace. This objective also belongs to the realm of idealism. Nigeria, with her level of development, appears to be inconsequential in the power equation in the world. That notwithstanding, she did try to contribute to the maintenance of world peace. She had involved herself twice in Chad, assisted in quelling the mutinies in Uganda and Tangayika in 1964. Her role during the Congo crisis was hailed by other members of the international system. The country also participated actively in the UN peace keeping in Lebanon in the 1970s. Indeed, Nigeria, due to her impressive outings at the various UN peace keeping operations, is being regarded a peace keeping nation.

At this juncture, we want to consider an issue which has been a subject of dispute for a while. While some scholars have commended the country's African policy, many others have criticized it for its lack of reciprocity. George Obiozor belongs to the second group of scholars, hi his view, Nigeria must do a kind of stock taking of those African states that we had assisted and see in what way such assistance has yielded return for her. In his own words:

What we are saying is that any foreign policy that does not insist on reciprocity is simply moralistic and infantile; for in the game of nations, there can be no permanent friends or permanent enemies for only circumstances determine which course a nation will take to protect its own national interests as conditions and circumstances change. ${ }^{30}$

Obiozor shares this view with Joe Garba. The latter, in his book: Diplomatic Soldiering, used the Angolan case as a basis for his admonition on the imperativeness of the principle of reciprocity in the conduct of Nigeria's African policy. ${ }^{31}$

In the midst of the debate on the desirability of the principle of reciprocity in Nigeria's foreign policy which expanded in scope to embrace the West, consequent upon the diplomatic showdown between the Buhari regime and the Thatcher administration over the attempted abduction of Umaru Dikko in 1984, the Babangida military administration emerged on the political scene. The section that follows immediately attempts to see how the Babangida regime wriggled out of the controversy using its publicized thrust of economic diplomacy. 
Nigeria-Africa Relations Under Economic Diplomacy, 1988-1992

\section{THE BABANGIDA ERA, 1988-1992}

We will approach our analysis under this heading from the economic, political, social and military dimensions of the relationship.lt is hoped that these categorizations will assist us to appreciate Nigeria's African relations under economic diplomacy. However, it is appropriate if we attempt a brief discussion of economic diplomacy as it relates to the issue we are investigating. Ordinarily, the authors of economic diplomacy would have preferred it to serve as a framework for undiluted conformism to the imperatives of imperialism. ${ }^{32}$ There is, however, a snag here. Nigeria was already occupying a leadership position in Africa. Obviously, this contradiction is not a mean'one. The concept of economic diplomacy which W. O. Alii has likened to commercialization of foreign policy presupposes marketing Nigeria for importation of capital and exportation of goods. ${ }^{33}$ In view of the economic situations in the African continent, it would appear not to be a crucial consideration in this regard.

Yet, in his first foreign policy address in 1988, Dee Nwachukwu said that the emphasis of the Babangida regime on economic gains of foreign policy would not mean the relegatipn of the country's tested traditional political commitments. ${ }^{34}$ This, of course, means continuing with the African centre-piece policy. What we will do in this section of the paper, therefore, is to really see how far the pursuit of economic diplomacy with its strong emphasis on imperialist states under Babangida's administration improved or undermined Nigerian's African Policy between 1988-1992.

\section{ECONOMIC RELATIONS}

Consequent upon the adoption of economic diplomacy in Nigeria, the country's investment policy in Africa was reviewed to be in harmony with the current mood in her economy. More attention was focused on the sugar and cement projects in Benin to cover the shortfall in domestic production. ${ }^{35}$ The relative progress made in the steel project in Nigeria led to more emphasis on the country's investment in iron ore in Guinea and Liberia. The carnage in Liberia, however, made emphasis shift to the former and other sources to satisfy the iron ore needs of the steel project. In 1991, Nigeria increased the number of fishing trawlers in Equatorial Guinea from seven to 17 and the licence fee paid per vessel was also increased, wo years earlier, after it had been confirmed that Equatorial Guinea was hob-nobbing with the racist regime in South Africa, and in attempt to wean the former from latter, Nigeria extended a NIOm life line to Equatorial Guinea to buy some essential commodities. ${ }^{36}$ This and other cash hand-outs which the country readily gave, however, worked against the 


\section{Annals of The Soda] Science Council of Nigeria, No. 7, January-December, 1995}

realization of the objectives of economic diplomacy. A regime of prudence would have served its cause better. To underscore the economic interdependence between them, two treaties were signed in 1991 and 1992 between Niger and Nigeria under which the former would supply meat to the latter.

One of the biggest problems confronting African economic development is the high level of indebtedness. During the period under review, various programmes and strategies were adopted to address the issue. Nigeria, in her capacity as the chairman of the OAU, delivered an address to the UN General Assembly highlighting the gravity of the African economic crisis. In the speech, Ibrahim Babangida reviewed the achievements of the UN Programme of Action for Africa launched in 1986 and considered the document as a mild response to the problem. From the speech, the position of Africans was that their debt was unrepayable. As a solution to the crisis, the OAU chairman called for debt forgiveness which should be accompanied by a massive injection of funds into Africa under the name of reparation. ${ }^{37}$ However, the negative trend in the outflow of resources from Africa continued despite the efforts by Nigeria on behalf of Africa. ${ }^{38}$

As a stop-gap towards the final integration of African economies, the ECOWAS experiment was being made to work by Nigeria.Through the adoption of the liberalization scheme, there was more free movement of persons and services within the community, hi view of the centrality of ECOWAS in the implementation of economic diplomacy, Nigeria legalized the duty-free importation of unprocessed and handicraft goods emanating from ECOWAS..$^{39}$ However, it was observed that the bad state of the economy under economic diplomacy made Nigeria to review her Trust Fund in the African Development Bank (ADB) and even turned her into a great competitor for ADB loans. ${ }^{40}$ Not only that, in 1989, ECOWAS alone sponsored two projects in Nigeria. ${ }^{41}$

In terms of trade relations, economic diplomacy did not make much of an impact on Nigeria-Africa relations, ha 1992, for instance, out of Nigeria's total export of $\mathrm{N} 82,875.7 \mathrm{~m}$, Africa only accounted for $\mathrm{N} 3,808.2 \mathrm{~m}$. Its percentage value though increased slightly to 7.6 per cent. ${ }^{42}$ When this percentage is viewed in global terms, it can be seen that it was not really significant in any way. The situation in the import sector reveals a similar trend. ${ }^{43}$ When these essential elements in the economic relationship are compared with the situation before 1988, it can be seen that Nigeria's African policy then showed more bite due to a strong economic base. The difference in economic situations, therefore, constrained the country to assume the proper role of an economic crisis averter, not economic crisis solver. ${ }^{44}$ 
Nigeria-Africa Relations Under Economic Diplomacy, 1988-1992

\section{Political Relations}

Between 1988-1992, the wave of democratization was quite strong in Africa. Every country was fashioning one form of transition programme or the other. Nigeria was not an exception. Indeed, African leaders were coming to Nigeria to learn the secrets of her democratic transition. ${ }^{45}$ At the 1991 OAU Summit Conference held in Abuja, Ibrahim Babangida had advised those sit-tight African leaders to democratize hi order not to be swept away disgracefully by the wind of democratic change.

On a general note, the relationship between Nigeria and African States was very cordial perhaps because of shared common interests on most political issues. Within the period, Nigeria played the role of an arbiter on the intractable Sudanese crisis. ${ }^{46}$ The conflict involving Ghana and Togo over the unification of all Ewe people was resolved through the utilization of Nigeria's good offices. Similarly, the Senegal -Mauritania crisis which had assumed a racial dimension was resolved through the assistance of Nigeria. ${ }^{47}$

However, cases of border conflict were rampant during the period. Despite the assurances given by the Cameroonian Defence Minister in early 1992, the conclusion of a joint boundary commission agreement in which peaceful means were preferred in the resolution of the border crisis was signed and a host of other diplomatic efforts made, the Nigeria-Cameroon border conflict remained the most fiercely contested issue in Nigeria's African policy between 1988-1992. Of course, there were also border conflicts with Chad and Benin Republic but through diplomatic efforts, they were prevented from escalating. Apartheid was another element of political relations within the period. The release of Nelson Mandela in 1990 and the qualified moves towards dismantling Ap'artheid then were greeted by some African countries as spectacular. Cote d'lvoire, for example, felt that there was no point isolating South Africa any longer. However, a combination of factors crucial to the Babangida regime like Western Financial Support changed the attitude of Nigeria and made her receive President De-Klerk in April, 1992. The high level official visits between Nigeria and many African countries, no doubt kept the political relationships very warm.

It should be noted that the economic crisis in Nigeria did have some impact on the level of political relationship, although with regard to the African sector, Nigeria pretended all was well with her economy. The elaborate preparations made for the OAU Summit Conference held in Abuja in 1991 illustrate this fact. ${ }^{48}$ But beyond the fanfare of the OAU Summit, Nigeria's political relations with Africa were qualitatively adversely affected by the realities of the economy. Her Volte face on the Apartheid issue was a clear pointer to the impact of economic crisis on Nigeria's foreign policy during the period. Ironically, this scenario contradicted Ike 
Nwachukwu's argument in 1988 that old political commitments would be pursued together with the new emphasis on economic goals. Joe Garba was thus vindicated in his assertion that economic considerations consumed political objectives in the pursuit of Babangida's foreign policy. ${ }^{49}$

\section{Social Relations}

The drug issue constituted an important element in Nigeria-Africa relations. Despite the efforts made by the country to curb it, African countries, due to Western propaganda, believed that she was a drug point. Another issue that featured under the relationship was the harassment of Nigerians in some African countries. Gabon topped the list of countries hostile to Nigerians. ${ }^{50}$ Libya was particularly incensed by the attitude of those Nigerians who were using her as an escape route to Europe and the USA.

Refugee problem was very severe between 1988-1992. The traffic of Liberian refugees coming to Nigeria and other African countries was quite heavy. Sierra Leone's security network was threatened by the influx of refugees from Liberia and this necessitated some concern by Nigeria. ${ }^{51}$ The country was, however, groaning under the weight of economic crisis as she was rehabilitating the Liberian refugees during the period. Nigeria's experience informed the continuous official attacks on the Western World over their lukewarm attitude towards Liberia. Still under social relations, the operational efficiency of the Federal Roads Safety Commission (FRSC) in Nigeria drew some admiration from African countries. They were really impressed by the remarkable reduction in the number of road accidents in Nigeria. The interest shown by African states led to some collaborative efforts between the FRSC and some African states. ${ }^{52}$

\section{Military Relations}

Nigeria has been involved in the Liberian crisis since its eruption in 1990. She was the brain behind the formation of ECOMOG, put together to restore sanity to war torn Liberia. Despite her attendance at the Yamoussoukro, Cotonou and Geneva Conferences on Liberia, Nigeria seemed to lack the capacity to resolve the crisis militarily. Yet, many more of the country's soldiers were sent to Somalia. President Siad Barre, whose misrule had brought about the carnage in the first instance was gracefully treated in Lagos. Although Nigeria's troops were there as a contingent of the UN Peace Keeping Force, Somalians had come to identify them as their enemies because of the political asylum granted their fleeing president, Said Barre. Within the same period, a battalion of the Nigerian army was sent to Sierra Leone to protect 
the country against the rampaging Charles Taylor's troops. A Nigerian army General •as sent there to reform her army as a component of Sierra Leone's request.

Apart from peace keeping, bilateral military relations also took place between Nigeria and some African countries. One of such was the visit of the Kenya delegation : the country to request for more exchange programmes between the Kenyan Command College and the Nigerian Command and Staff College, Jaji. More military contacts also took place between Nigeria and Egypt during the period. Curiously, we observe that the period of our research which was officially considered a period of commercialization of external relations ironically was the period when the country's military activities across the globe received a boost. The country thus positioned herself in contradiction of the rather too many economic objectives which economic diplomacy was set to achieve.

\section{CONCLUDING REMARKS}

Nigeria, between 1988-1992, pursued the African centredness of her foreign policy. Although all indicators of the level of economic interaction between her and other African countries remained hopelessly negative as they were before the advent of economic diplomacy (see the preceding discussions on economic relations); the level of unrecorded trading activities increased in view of the massive devaluation of the naira which made other African currencies more powerful than it. ${ }^{54}$ Consequently, used materials called "Tokunbos" imported through the country's neighbours became a common feature of the Nigerian market. ${ }^{55}$

At the official level, Nigeria assumed the proper role of a spokesman for Africa. ${ }^{56}$ The financial base of playing such a role which had made her voice to carry weight in the past was, however, eroded. At a rhetorical level, Nigeria pursued the centrality of Africa in her external relations but once there was a clash, even a potential one for that matter, between it and the Western interest, the centre-piece principles was compromised. ${ }^{57}$

Consequently, while the conclusions which Sam Oyovbaire and Tunji Olagunju have drawn on Nigeria's foreign policy under the Babangida regime were not totally unexpected ${ }^{58}$ the ones made by Joy Ogwu and Adebayo Olukoshi on the impact of economic diplomacy on Nigeria's African policy bear some relevance to reality. ${ }^{59}$ Its pursuit was more guided by the mood of the industrialized Western countries on whom the authors of economic diplomacy put their stakes. The volte face of Nigeria on the Apartheid state in April 1992 when president Frederick De Klerk was hosted in Abuja despite the then reversible steps being taken towards dismantling the obnoxious Apartheid policy serves as an eloquent testimony of our case. 
138 Annals of The Social Science Council of Nigeria, No. 7, January-December, 1995

\section{NOTES AND REFERENCES}

1. For instance, John Mackintosh, Nigerian Government and Politics. Evanston: North Western University Press, (1960).

2. Toyin Moyosore, "Nigeria's Historic Mission in Africa: Is She Still Relevant in African Affairs?" Nigerian Forum ,Vol. 10 Nos. 1\&2, January/February, 1990, pp.33-34.

3. George A. Obiozor, (ed.) Basic Issues in Nigerian Foreign Policy: IBB's Foreign Policy Pronouncements (1986-1991) (Lagos, NIIA, 1992), p.50.

4. Jide Oshuntokun, "Nigerian's Post Independence Foreign Policy: The Shift from Political Concerns to Economic Diplomacy". National Concord, 28 September, 1989, p.7

5. I. O. S. Nwachukwu, "The Dynamics of Nigeria" Lecture delivered at NIIA, Lagos, 30 June, 1988.

6'. $\quad$ Nigeria's Economic Diplomacy: The Ike Nwachukwu Years, 1988-1992 (Abuja, Ministry of Foreign Affairs, 1992), pp. 51-66.

7. Ike Nwachukwu stated this. See, National Concord, 10 October 1989, p.7

8. Performance and Achievements of the Ministry of External Affairs under the Babangida Administration, August, 1985-December 1990 (Lagos, Ministry of External Affairs, 1991) p. 5

9. Ojetunji Aboyade, "Nigeria's Economic Diplomacy", Business Times, 31 December 1990, p. 5.

10. Joy Ogwu and Adebayo Olukoshi, "Economics and Diplomacy in the World System: Some Perspectives" in Joy Ogwu and Adebayo (eds) Economic Diplomacy in the Contemporary World and the Nigerian Experience (Lagos, NIIA, 1991), p.9.

11. I. O. S. Nwachukwu's interview in African Concord, 10, June 1991, p.40.

12. A. G. Frank, On Capitalist Development (Bombay, Oxford University Press, 1975).

13. Nwachukwu, "The Dynamics of Nigeria's Foreign Policy".

14. S. Ayo Amale, "Constraints of Nigeria's Economic Diplomacy" in Joy Ogwu and Adebayo Olukoshi (eds) The Economic Diplomacy of the Nigerian State (Lagos, NIIA, 1991) p. 116.

15. M. O. Igboeli, "Principles and Dynamics of Nigerian Foreign Policy, 1960-1979" ECPER Journal, Vol. H, No.2, (1994) p.70. 
16. T. A. Imobighe, "The Long Road of Nigeria's Africa-Centred Foreign Policy". T. A. Imobighe (ed) Nigeria's Policy in the Eighties (Kuru, NTPSS, n.d).

17. Ibrahim A. Gambari, Party Politics and Foreign Policy: Nigerian under the First Republic (Zaria, ABU Press, 1980).

18. Kunle Adeyemi, "Keynote Address on Nigeria's Foreign Policy" S. G. Tyoden (ed) Nigeria's Foreign Policy: Summary of the Proceedings of a Seminar (Kuru, NIPSS, 1984).

19. Ibrahim A. Gambari, Theory and Reality in Foreign Policy Decision Making: Nigeria After the Second Republic (New Jersey, Humanities Press International, 1989).

20. Ibid.

21. Jaja Wachukwu has objected to this view in his article entitled: "Our Foreign Policy was Pragmatic, not low key" The Guardian (Nigeria) 4 October, 1987.

22. Economic Considerations featured Prominently in the Thinking of African Countries in Declaring Support or Otherwise for Biafra.

23. Bolaji Akinyemi, "The Colonial Legacy and Major Themes in Nigeria's Foreign Policy" A.B. Akinyemi, S.O. Agbi and A.O. Otunbajo (eds) Nigeria Since Independence: The First Twenty-five Years (Ibadan, Heinemann Educational Books Nigeria, 1989).p.20

24. Bolaji Akinyemi, "Two Years of Nigeria's Foreign Policy: A Self Assessment" Sunday Concord 23 August, 1987, pp. 12 \& 14.

25. Imobighe, "Long Road to Nigeria's African-Centre Foreign Policy" op.cit. p. 13.

26. Adekunle Ajala, "Nigeria and Southern Africa" G. O. Olusanya and R. A. Akindele (eds) Nigeria's External Relations: The First Twenty Five Years (Ibadan, University Press, 1986) pp. 196-208.

27. Olajide Aluko, "Nigeria and the Organization of African Unity" Olusanya and Akindele (eds) Nigeria's External Relations: The First Twenty Five Years.

28. I.O.S. Nwachukwu's keynote Address at the NSIA Conference at the NHA Lagos November 1990.

29. Olajide Aluko, Essays in Nigerian Foreign Policy (London, George \& Unwin, 1981)

30. George A. Obiozor, "Significant Variables in Nigeria's External Relations" Nigerian Forum, Vol. 7, Nos. 9 and 10. 
140 Annals of The Social Science Council of Nigeria, No. 7, January-December, 1995

31. Joe Garba, Diplomatic Soldiering (Ibadan, Spectrum Books Limited, 1987).

32. Joy U. Ogwu and Adebayo Olukoshi, "Nigeria's Economic Diplomacy; Some Contending Issues" Joy Ogwu and Adebayo Olukoshi (eds) The Economic Diplomacy of the Nigerian State (Lagos, NIIA, 1991) p.13.

33. W. O. Alii, "Economic Diplomacy in Nigeria: Content, Institutional Mechanism land Processes" NSIA Conference (NIIA) 1990.

34. Nwachukwu, "The Dynamics of Nigerian Foreign Policy".

35. Nigeria: Bulletin on Foreign Affairs, June, 1990. p.1

36. Nigeria: Bulletin on Foreign Affairs, 1989, p.21

37. Ibrahim Badamasi Babangida Address to the UN General Assembly, October 1991.

38. Boutros Ghali, "New Concepts of Development Action in Africa" Department of Public Information, UN December, 1992. p.2

39. Ibrahim Badamasi Babangida, NIIA Patron Night Speech, 1992.

40. Nigeria: Bulletin on Foreign Affairs, June 1990. p. 10

41. Nigeria: Bulletin on Foreign Affairs, 1989, p.21

42. 42. Federal Office of Statistics. Review of the Nigerian Economy 1992, (Lagos, FOS, 1992)p.27

43. Ernest Shonekan, The Nigerian Trade Journal, Vol. 35, No. 3, July/September 1991. pp. 38-42.

44. Nigeria $s$ Foreign Policy: Summary of the Proceedings of a Seminar, p.34 Rilwanu Lukman's Address to the 18th Special Session of the UN General Assembly, 25 April, 1990.

45. For instance, Idris Derby of Chad's visit in 1992.

46. Nigeria: Bulletin on Foreign Affairs, December, 1992.

47. Sam Oyovbaire and Tunji Olagunju, Foundations of a New Nigeria: The IBB Era (Ibadan, Precision Press, n.d) p.64.

48. Hassan A. Salisu, "Political Economy of Nigeria's Political Transition to Civil Rule Programme 1985-1993" ECPER Journal, Vol. III. No. 2 (1995).

49. Joe Garba, The Honour to Serve (Ibadan, Macmillan, 1993).

50. Bulletin, December, 1991. p.8

51. Bulletin, June 1990. p.9 
52. Bulletin, 1992, p.9

53. Hassan A. Salisu, "The Impact of Debt Crisis on Nigeria's Foreign Policy During the Transition Period" PASS Seminar, NDA, 31 May, 1991.

54. Hassan A. Salisu, "A Critique of the Foundations of a New Nigeria: The IBB Era" Journal of Social and Management Studies, Vol. I, No. 1, 1994.

55. Ibid.

56 Hassan A. Salisu, "Economic Diplomacy as a New Phase of Nigeria's External Relations: A Critical Assessment" Ph.D Dissertation Department of Political Scibnce, BUK, August, 1994. pp. 339-347.

57. Ibid.

58. Oyovbaire and Olagunju, Foundations of a New Nigeria: The IBB Era.

59. Joy Ogwu and Adebayo Olukoshi, "Nigeria's Economic Diplomacy: Some Contending Issues" Joy Ogwu and Adebayo Olukoshi (eds) The Economic Diplomacy of the Nigerian State (Lagos, NIIA, 1991) p.9. 